\title{
The Regenerative Potential of Managed Calluna Heathlands-Revealing Optical and Structural Traits for Predicting Recovery Dynamics
}

\author{
Carsten Neumann ${ }^{1, *(1)}$, Anne Schindhelm ${ }^{1,2}$, Jörg Müller ${ }^{3}$, Gabriele Weiss ${ }^{2}$, Anna Liu ${ }^{4}$ and Sibylle Itzerott ${ }^{1}$ \\ 1 Helmholtz Centre Potsdam GFZ German Research Centre for Geosciences, 14473 Potsdam, Germany; \\ anne.schindhelm@ecostrat.de (A.S.); sibylle.itzerott@gfz-potsdam.de (S.I.) \\ 2 Ecostrat GmbH Berlin, 12203 Berlin, Germany; gabriele.weiss@ecostrat.de \\ 3 Heinz Sielmann Foundation, 14641 Wustermark (OT Elstal), Germany; joerg.mueller@sielmann-stiftung.de \\ 4 Geoinformation in Environmental Planning Lab, Technische Universität Berlin, 10623 Berlin, Germany; \\ anna.liu@campus.tu-berlin.de \\ * Correspondence: carsten.neumann@gfz-potsdam.de; Tel.: +49-331-288-1766
}

Citation: Neumann, C.; Schindhelm, A.; Müller, J.; Weiss, G.; Liu, A.; Itzerott, $\mathrm{S}$. The Regenerative Potential of Managed Calluna Heathlands-Revealing Optical and Structural Traits for Predicting Recovery Dynamics. Remote Sens. 2021, 13, 625. https://doi.org/ $10.3390 /$ rs13040625

Academic Editor: Duccio Rocchini Received: 14 January 2021

Accepted: 3 February 2021

Published: 9 February 2021

Publisher's Note: MDPI stays neutral with regard to jurisdictional claims in published maps and institutional affiliations.

Copyright: (c) 2021 by the authors. Licensee MDPI, Basel, Switzerland. This article is an open access article distributed under the terms and conditions of the Creative Commons Attribution (CC BY) license (https:// creativecommons.org/licenses/by/ $4.0 /)$.

\begin{abstract}
The potential of vegetation recovery through resprouting of plant tissue from buds after the removal of aboveground biomass is a key resilience strategy for populations under abrupt environmental change. Resprouting leads to fast regeneration, particularly after the implementation of mechanical mowing as part of active management for promoting open habitats. We investigated whether recovery dynamics of resprouting and the threat of habitat conversion can be predicted by optical and structural stand traits derived from drone imagery in a protected heathland area. We conducted multivariate regression for variable selection and random forest regression for predictive modeling using 50 spectral predictors, textural features and height parameters to quantify Calluna resprouting and grass invasion in before-mowing images that were related to vegetation recovery in after-mowing imagery. The study reveals that Calluna resprouting can be explained by significant optical predictors of mainly green reflectance in parental individuals. In contrast, grass encroachment is identified by structural canopy properties that indicate before-mowing grass interpenetration as starting points for after-mowing dispersal. We prove the concept of trait propagation through time providing significant derivates for a low-cost drone system. It can be utilized to build drone-based decision support systems for evaluating consequences and requirements of habitat management practice.
\end{abstract}

Keywords: resprouting; habitat management; heathland; trait mapping; UAV

\section{Introduction}

Resprouting, the process of regenerating plant tissue from meristematic cells after substantial loss of aboveground biomass, is a key functional trait for fostering population persistence against abrupt environmental changes [1-3]. Besides seedling recruitment, it plays a major role for the longevity of individuals under the influence of recurrent disturbance regimes. Vegetative regeneration is thus well described as regrowth in natural ecosystem dynamics such as in various fire regimes [4,5], after drought events [6] or under herbivory influence [7]. Although there is evidence that resprouting depends on the type of disturbance and its affecting plant species [8,9], little is known about population-level growth responses in managed ecosystems. For example, the removal of vegetation layers by measures of controlled fires, grazing or mechanical mowing are crucial for maintaining open landscape mosaics. In fact, mowing, as a process of active clipping, is particularly one of the most important technical tools for an area-wide management of plant growth in open habitats. In this regard, habitat management is seen to be essential for preserving biodiversity in semi-natural landscapes [10-12]. 
Heathlands are representing one type of traditional European semi-natural landscapes bearing high biodiversity values and promoting the provision of ecosystem services with particular high importance such as carbon storage, aesthetic value and recreation value [13-15]. They are dominated by the dwarf-shrub species Calluna vulgaris (L.) Hull (hereinafter referred to as Calluna) that form a unique ecosystem as part of the European network of managed conservation areas. Habitat management is crucial for the maintenance of Calluna heathlands since traditional forms of land use are neglected and a strong decline in habitat extent and degradation of habitat quality can be observed over the last decades $[14,16]$. In various years of fire and mowing management of European continental dry heaths, particularly on former military training areas, it has been found out that population-level recovery is dominated by resprouting from the stem base of Calluna individuals [17-19]. The dominance of resprouting can potentially contribute to the management goals regarding Calluna density, stand vitality and reproductive capacity if there is a relatively young population age structure ( $<15$ years) affected $[20,21]$. It can even be beneficial to facilitate resprouting in mature life-cycles phases since resprouting is fast, also under unfavorable growth conditions [22]. As a consequence, it suppresses tree colonization, provides vigorous young shoots $[20,23]$ and increases the generation of flowers as pollination habitats [19].

However, a permanent facilitation of resprouting can induce negative effect on habitat conservation since it does not affect the age structure of a population. In this regard, the regenerative potential of Calluna is known to be decreased significantly with age [20,22,24]. Resprouting without regeneration over seedling recruitment leads to a gradual loss of vitality and density in Calluna stands which opens up the populations for ecosystem conversion such as grass invasion. As a consequence, it was suggested to occasionally remove the upper vegetation layer by sod-cutting in order to effectively promote germination which triggers the generation of diverse life-cycle phase patterns in Calluna heathlands $[11,17,25]$. Keeping this in mind, conservation managers need to carefully evaluate beforehand whether a potential management success can be ensured by the implementation of selected management measures. To actively control population persistence through extension of vitality and reproduction, it is of utmost importance to gain an early understanding of the potentials and dynamics of Calluna regrowth after management.

Since resprouting is realized from buds at the stem base of parental plants [20] there is a hypothetical link between optical and structural traits of parental growth and the shoot density of the following generation. Furthermore, we hypothesize that closed Calluna stands are often interpenetrated by more or less dense grass patches which form starting points for grass species expansion that becomes dominant after management. On that account, we state that there are distinctive traits on the plant unit as well as on the stand level that can be defined as indicators before management to predict resprouting and grass encroachment after management. Although management dynamics need to be evaluated for an area-wide monitoring, rejuvenating shoots as well as grass invasion are potentially observable on a small scale that reveals plant traits on the leaf level. Such scale-appropriate monitoring tasks can be realized by easily accessible and affordable RGB-drone cameras mounted on unmanned aerial vehicles (UAVs) [26].

Recently, UAVs are implemented to spatially map optical and structural vegetation characteristic using machine learning techniques for, e.g., plant species mapping [27-29] or plant phenology evaluation [30]. Beyond conventional mapping approaches there is surprisingly no predictive modeling presented that utilizes multitemporal growth dynamics as product for the evaluation of management impacts [31]. In this regard, Calluna management by mowing on typically 10 ha sized areas allows to track regrowth dynamics at a feasible scale for drone-based monitoring applications. We therefore ask:

Are there optical and structural traits that can be mapped in RGB-drone imagery before mowing to predict:

A. The potential resprouting of Calluna heath,

B. The potential threat of grass invasion in heathland sites? 


\section{Materials and Methods}

\subsection{Study Area and Field Survey}

The study was conducted on the former military training area, Kyritz-Ruppiner Heide, located in the north-west of the federal state Brandenburg, Germany (center coordinates: $53^{\circ} 05^{\prime} 42.62^{\prime \prime} \mathrm{N} ; 12^{\circ} 39^{\prime} 28.79^{\prime \prime} \mathrm{E}$ ) (Figure 1). The area is considered to be one of the largest unfragmented heathland areas in Europe, comprising an area of $120 \mathrm{~km}^{2}$ that is designated as a Site of Community Importance (DE2941302). Due to its protection status within the European Natura 2000 network [32], open heathlands are maintained by active management such as controlled burning, tree removal and mechanical mowing.

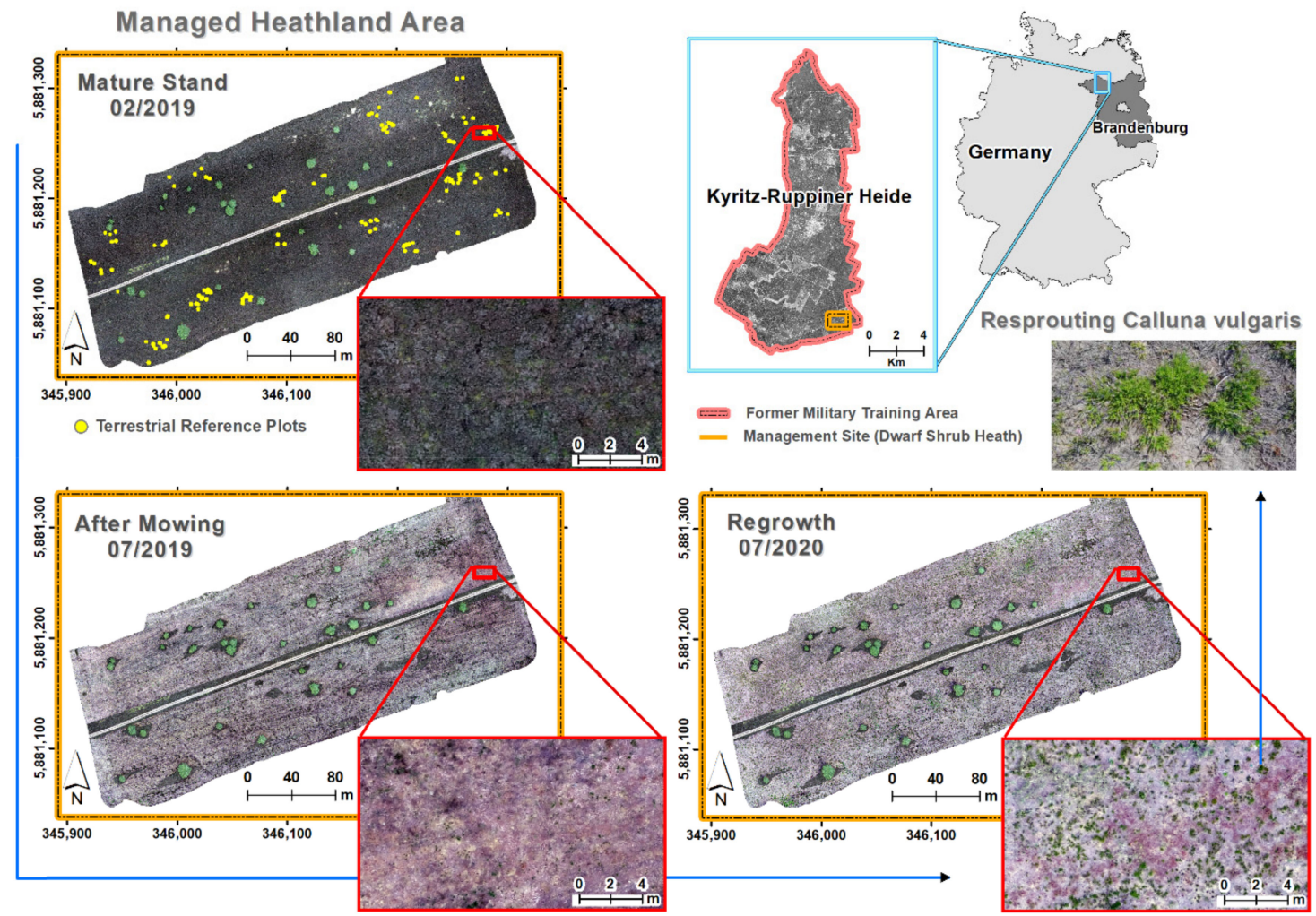

Figure 1. Location of Calluna Heathland test site before and after mowing management; images are generated as red-greenblue true-color composites from drone flights in consecutive seasons; Calluna resprouting and associated plant species are mapped on reference plot samples in the field.

As a result, on sandy acidic nutrient-poor soils a diverse habitat mosaic arose consisting of heather (Calluna vulgaris), pioneer dry grasslands (e.g., Corynephorus canescens, Carex arenaria, Agrostis capillaris), fruticose lichens (e.g., Cladonia mitis, Cladonia coccifera, Cetraria aculeata), apocarpic mosses (e.g., Polytrichum piliferum), and pleurocarpic mosses as degeneration phase (e.g., Pleurozium schreberi, Hypnum jutlandicum). Habitat conversion is mainly caused by natural succession and related species turnover of invading shrubs (Sarothamnus scoparius, Rubus spec.), trees (Betula pendula, Pinus sylvestris, Populus tremula) or grasses (Calamagrostis epigejos, Deschampsia flexuosa). Calluna regeneration is limited by low precipitation (annual rainfall average of $560 \mathrm{~mm}$ ), winter frosts and a strong continental climate seasonality of the temperate zone. The test site that covers an area of 6.6 ha was mowed by machine during winter time on 13th February 2019 (Figure 1). Vegetation traits were measured on terrestrial field plots $n=178$ between 3rd and 8th September 2020 in the consecutive year after 2 growing seasons. 


\subsection{UAV Image Processing}

Images were recorded regularly before and after mowing using a DJI Phantom 4 Pro quadcopter that carries a RGB filtered 1-inch complementary metal-oxide semiconductor sensor (CMOS) with a resolution of 20 megapixel. For each flight $300-400$ scenes were recorded and saved as digital numbers (DN) in 8-bit jpeg imagery for an average area of $10 \mathrm{ha}$. We used autonomous flight planning with an overlap of $80 \%$ along and across track and a flight altitude of $80 \mathrm{~m}$ above ground which resulted in flight times of about $25 \mathrm{~min}$. In order to maximize $\mathrm{DN}$ spread in the 8-bit grey-value image representation, the flights were conducted under diffuse irradiance conditions of complete cloud coverage. The single images were combined to an image mosaic on the basis of 3D point cloud generation in a structure from motion (SfM) approach provided by Pix4D cloud $[33,34]$. Finally, three image mosaics were processed in the after-mowing period $(24 / 07 / 2020$, $08 / 09 / 2020,02 / 10 / 2020)$ and two images before mowing $(06 / 04 / 2018,13 / 02 / 2019)$. The images were co-registrated using manually selected ground control points and bilinearly resampled to a pixel size of $2.1 \mathrm{~cm}$. The final image extent was clipped to an actual mowing area mask (6.6 ha) that excludes large trees and unmown patches.

Predictor variables were extracted from the image mosaics and included as additional layers depending on before and after mowing analysis (Table 1). The nine RGB channels for the three image mosaics after mowing were replaced by brightness corrected layers applying an RGB to hue, saturation, value (HSV) color space transformation. Textural features were calculated on the basis of the $08 / 09 / 2020$ green channel using a grey level co-occurrence matrix [35] in a $5 \times 5$ pixel moving window. Only the six least-correlated textures (mean, variance, homogeneity, dissimilarity, entropy, angular second moment) [36] were supplemented which results in a final layer stack of $n=15$ images that was used as input for after-mowing vegetation classification. To test the before-mowing hypotheses, RGB grey-values, RGB-HSV transformed values, RGB chromaticity values [19], uncorrelated textures from the green channel of the respective scene and an additional number of $n=8$ spectral indices were calculated for each image (Table 2).

Table 1. Matrix of predictor variables derived as image layers to calibrate after-mowing classification and perform regression analysis in before-mowing images; predictors can be grouped into representing plant traits and relief-based indices.

\begin{tabular}{|c|c|c|c|c|c|c|}
\hline \multicolumn{4}{|c|}{$\begin{array}{l}\text { After-Mowing } \\
(\mathrm{n} \text {-Layers = 15) }\end{array}$} & \multicolumn{2}{|c|}{$\begin{array}{l}\text { Before-Mowing } \\
\text { (n-Layers = 48) }\end{array}$} & \multirow[t]{2}{*}{$\begin{array}{c}\text { DEM } \\
(\text { n-Layers }=2)\end{array}$} \\
\hline image dates & $24 / 07 / 2020$ & $\begin{array}{c}08 / 09 / 2020 \\
\text { optical traits }\end{array}$ & $02 / 10 / 2020$ & $06 / 04 / 2018$ & $13 / 02 / 2019$ & \\
\hline RGB grey-values & - & - & - & 3 & 3 & - \\
\hline RGB-HSV transformed & 3 & 3 & 3 & 3 & 3 & - \\
\hline RGB chromaticity & - & - & - & 3 & 3 & - \\
\hline spectral indices & - & - & - & 8 & 8 & - \\
\hline \multicolumn{6}{|c|}{ structural traits } & - \\
\hline green texture & - & 6 & - & 6 & 6 & - \\
\hline \multirow[t]{2}{*}{ canopy height } & - & - & - & 1 & 1 & - \\
\hline & & micro-relief & & & & - \\
\hline topographic wetness index & - & - & - & - & - & 1 \\
\hline slope-length factor & - & - & - & - & - & 1 \\
\hline
\end{tabular}


Table 2. Spectral indices calculated as additional layers from the before-mowing images; RGB = red-green-blue channels for 8-bit image digital numbers (grey-values).

\begin{tabular}{cccc}
\hline Index & Name & Equation & Citation \\
\hline VARI & Visible Atmospheric Resistant Index & $(\mathrm{G}-\mathrm{R}) /(\mathrm{G}+\mathrm{R}-\mathrm{B})$ & {$[37]$} \\
TGI & Triangular Greeness Index & $\mathrm{G}-0.39 \cdot \mathrm{R}-0.61 \cdot \mathrm{B}$ & {$[38]$} \\
NGRDI & Normalized Green Red Difference Index & $(\mathrm{G}-\mathrm{R}) /(\mathrm{G}+\mathrm{R})$ & {$[37]$} \\
MGRVI & Modified Green Red Vegetation Index & $\left(\mathrm{G}^{2}-\mathrm{R}^{2}\right) /\left(\mathrm{G}^{2}+\mathrm{R}^{2}\right)$ & {$[39]$} \\
RGBVI & Red Green Blue Vegetation Index & $\mathrm{G}^{2}-(\mathrm{R} \cdot \mathrm{B}) / \mathrm{G}^{2}+(\mathrm{R} \cdot \mathrm{B})$ & {$[39]$} \\
GLI & Green Leaf Index & $(2 \cdot \mathrm{G}-\mathrm{R}-\mathrm{B}) /(2 \cdot \mathrm{G}+\mathrm{R}+\mathrm{B})$ & {$[40]$} \\
EXG & Excess Green Index & $2 \cdot \mathrm{G}-\mathrm{B}-\mathrm{R}$ & {$[41]$} \\
DAVI & Daylight Adapted Vegetation Index & $\mathrm{G} /\left(\left(\mathrm{R}^{0.667}\right) \cdot\left(\mathrm{B}^{(1-0.667)}\right)\right)$ & {$[42,43]$} \\
\hline
\end{tabular}

Furthermore, a normalized digital surface model (nDSM) was extracted from the two before-mowing images in order to represent vegetation canopy heights [19]. We used a laser scan elevation model (DEM) with $1 \mathrm{~m}$ pixel size for reference ground-level heights provided by Landesvermessung und Geobasisinformation Brandenburg (LGB). The DEM was further used to calculate two additional topographic indices, the topographic wetness index (TWI) [44] and the slope length factor (LS) [45], for estimating the influence of abiotic site conditions that control, e.g., water availability for plant growth. In total 50 variables were extracted from the before-mowing images, 24 for each image acquisition date, supplemented by 2 DEM-based topographic indices (Table 1). The variables represent potential predictors from the groups of optical traits (RGB values and indices), structural stand properties (texture and canopy height) and the abiotic background of microrelief (topographic indices).

\subsection{Spatial Detection of After-Mowing Dynamics}

After-mowing regrowth dynamics are mainly characterized by two processes of (A) vegetative regeneration of Calluna, predominantly resprouting from the stem base of parental plants and (B) the invasion of grass species (Figure 2).
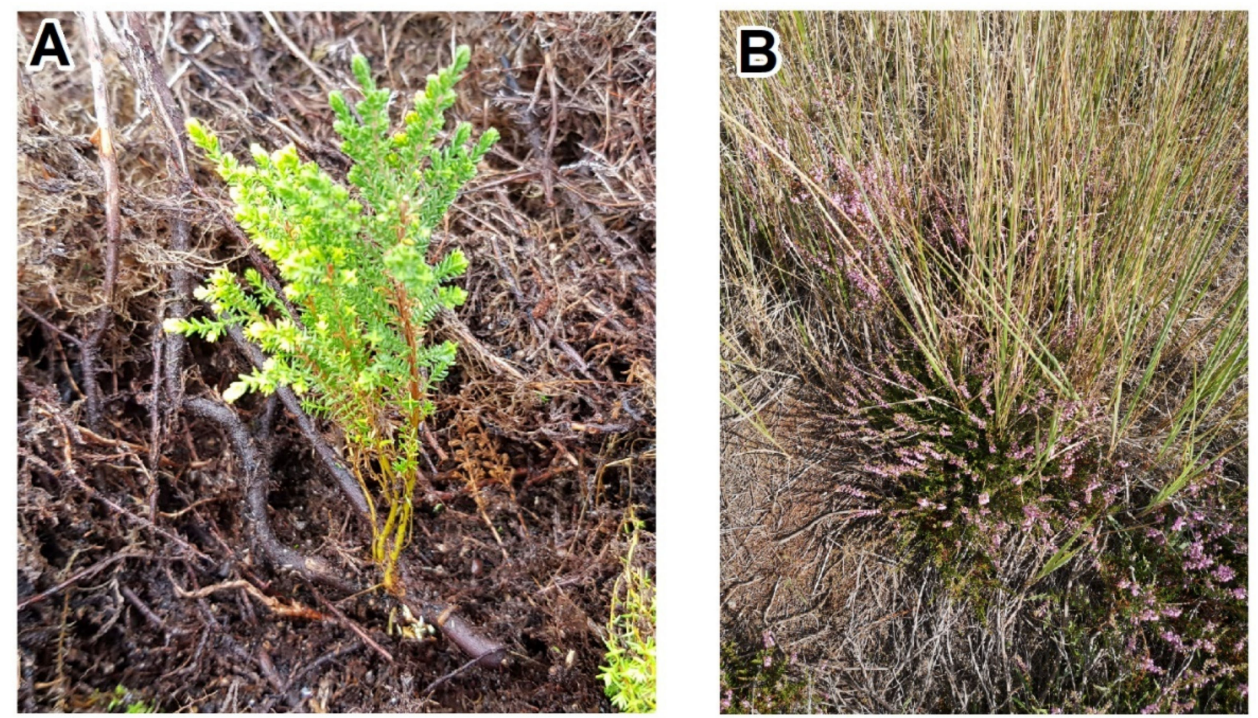

Figure 2. (A) resprouting of Calluna vulgaris from buds located at the stem base of parental individuals; (B) typical grass invasion of Calamagrostis epigejos that interpenetrates Calluna regrowth.

In order to fully cover the optical and structural diversity in UAV imagery, terrestrial field samples were surveyed for all grass, herb, dwarf-shrub and tree species that are likely to occur on the test site. Additionally, lichens, mosses, woody plant parts and the soil background were sampled in the field. Decision on sample ident was based on expert 
knowledge to cover all plant species and structural parameters in $n=23$ classes that were digitized as polygons on an UAV image directly in the field. The polygon area thus fully covers the visible area of the respective plant species or background parameter that was recognized in the field and subsequently delineated on the UAV image. There is no species mixture mapped. Sample idents are repeated to distribute sample locations over the entire test site. For model building, the sample idents were grouped together into $\mathrm{n}=7$ classes for which all pixels of totally $n=178$ polygons were extracted from the input image stack of $\mathrm{n}=15$ layers (Table 3 ).

Table 3. Aggregated classes used for after-mowing classification; related individual composition of field sample idents and number of extracted pixels using $\mathrm{n}=178$ polygons for each layer in UAV drone imagery.

\begin{tabular}{ccc}
\hline Class & Individuals & n-Pixels per Layer \\
\hline Calluna & Calluna vulgaris & 5292 \\
Grass & Calamagrostis epigejos, Agrostis capillaris, Carex arenaria; Carex pilulifera, Nardus & 3360 \\
Herb & stricta, Deschampsia flexuosa, Corynephorus canescens & 1753 \\
Litter & Rumex acetosella, Hypericum perforatum, Hieracium pilosella & 2090 \\
Cryptogams & Calluna vulgaris (dead, senescent branches) & 2271 \\
Shrub & Cladonia mitis, Cladonia coccifera, Cladonia furcata, Pleurozium schreberi, & 3030 \\
Background & Hypnum jutlandicum, Polytrichum piliferum & 1368 \\
\hline
\end{tabular}

We applied a random forest classification $[46,47]$ using grid search for parameter tuning which results in 500 trees and 5 layers per splitting node for the final model. The trees are grown until the maximum number of terminal nodes and majority votes are used for final class assignment. Validation and parameter tuning were done by generating a confusion matrix based on independent out-of-bag error estimates, i.e., overall accuracy (OA), user accuracy (UA) and producer accuracy (PA) $[48,49]$. The final model was applied for spatially explicit predictions on the image stack. Due to the high resolution of input imagery, single pixels of plant branches, leaves or inflorescences can be misclassified. This classification noise was re-assigned to broader clusters of pixel classes by selecting the most common class for the focal pixel applying a $5 \times 5$ pixel moving window (modal filter). To reconstruct true class boundaries a $5 \times 5$ pixel, erode filter was subsequently added.

Finally, the pixels of the classification results for the heath and grass class were extracted as binary grids. The two final classes were translated into density values by counting the number of class pixels for the focal pixel in a $51 \times 51$ pixels moving window spanned over the grids. This results in a data range of 0 (no class pixel)-2601 (all class pixels) for both binary class grids. Subsequently the number of class pixels was min-max transformed into a density range of $0-100 \%$ that was mapped in two new grids of the test site with $1 \mathrm{~m}^{2}$ pixel size. Each grid represents the continuous distribution of the response variables a) Calluna resprouting and b) grass encroachment that were finally extracted as response vectors using a stratified random sampling on the density classes for the statistical modeling. For this purpose, we reclassified the two density grids into 12 uniform classes. In each class a spatially random sample of size $=100$ pixel locations were selected. The extracted density values in a) and b) are defined as response range that is equally distributed over the entire density range comprising in total $n=1200$ samples for regression analysis.

\subsection{Statistical Modeling of Before-Mowing Predictors}

The same pixel locations that were defined as response variables $(a, b)$ were used to extract the predictor variables from the before-mowing image stack. There are two statistical techniques (A, B) that were applied in order to detect significant spectral predictors and model the potential of Calluna resprouting and grass encroachment on the beforemowing images. In technique A we performed multiple linear regression analysis with 
multicollinearity considerations for variable selection and model stability testing. In the first step the initial variable set was condensed by the number of only significant predictors ( $p$-value $<0.01$ ) based on univariate regression modeling. The new variable set was used as input into a multiple linear regression model with backward variable selection. For this purpose, the Akaike Information Criterion (AIC) [50] was calculated until an optimal set of predictors that minimize AIC was found. Due to the limited spectral information content in only three RGB values and derived products, the remaining predictor variables are highly correlated. The underlying effect of multicollinearity between spectral predictors was estimated using the variance inflation factor (VIF) [51]. It was calculated while successively reducing variables with highest VIF until a final set of predictors can be assigned that fulfil the condition of VIF $<5$. The resulting set of uncorrelated predictors was used to calibrate a final multivariate regression model using the adjusted $\mathrm{R}^{2}$, the root mean squared error (RMSE) as percentage of the response range and significance levels of the predictor's model coefficients to compare model qualities between techniques and response variables. The RMSE compares the after-mowing response variable distributions $(a, b)$ with the model predictions based on the before-mowing predictors.

In technique $\mathrm{B}$, a purely predictive modeling is conducted applying a random forest machine learning approach [46,47]. Here, we used all variables as model input with a randomly sampled variable size of $n=10$ per split. In total 500 decision trees were grown up to the maximum possible number of terminal nodes. Since random forest predictions are based on internal-averaging, there is a strong tendency of overfitting in model training [52,53]. In order to estimate the generalization error, an external crossvalidation was performed. Individual models were built on a stratified sample of a $75 / 25 \%$ training/test data split while model quality measures $\left(\mathrm{R}^{2}, \mathrm{RMSE}\right)$ were averaged over $100 \times$ test data predictions. The final model that incorporates all samples was used to predict the potential of resprouting and grass encroachment on the basis of before-mowing images. For the final model, a variable importance measure (VI) based on decreasing node impurities [47] was calculated to identify optimal predictor variables.

\section{Results}

\subsection{Spatial Patterns of Heathland Regeneration after Mowing}

The overall classification accuracy of after-mowing classes is high with $\mathrm{OA}=97.9 \%$ based on out-of-bag predictions using approximately one third of the 19.217 input pixels for cross-validation after bootstrapping of calibration samples [49]. The resprouting of Calluna is modeled almost perfectly $(\mathrm{PA}=99.09 \%)$ with slight decreases of pixel representations $(\mathrm{UA}=97.53 \%)$. In general, all classes can be delineated in drone imagery with high accuracies (OA, UA and PA $>96 \%$ ) while the background class is optimally discriminated against vegetation after mowing (UA, PA > 98\%) (Table 4).

Table 4. After mowing classification result from random forest out-of-bag predictions.

\begin{tabular}{|c|c|c|c|c|c|c|c|c|c|}
\hline & \multicolumn{9}{|c|}{ Classification } \\
\hline & & Calluna & Grass & Herb & Litter & Crypto & Shrub & Backgr. & $\begin{array}{c}\text { Producer's } \\
\text { Accuracy }(\%)\end{array}$ \\
\hline \multirow{8}{*}{ Reference } & Calluna & 5244 & 11 & 2 & 8 & 18 & 9 & 0 & 99.09 \\
\hline & Grass & 26 & 3309 & 10 & 6 & 9 & 45 & 0 & 97.18 \\
\hline & Herb & 10 & 10 & 1713 & 2 & 18 & 0 & 0 & 97.72 \\
\hline & Litter & 16 & 20 & 0 & 2029 & 15 & 0 & 10 & 97.08 \\
\hline & Crypto & 29 & 30 & 2 & 7 & 2201 & 0 & 2 & 96.92 \\
\hline & Shrub & 52 & 12 & 2 & 0 & 0 & 2964 & 0 & 97.82 \\
\hline & Backgr. & 0 & 8 & 0 & 12 & 2 & 0 & 1354 & 98.40 \\
\hline & User's accuracy (\%) & 97.53 & 97.32 & 99.07 & 98.3 & 97.26 & 98.21 & 99.12 & \\
\hline
\end{tabular}

The spatial distribution of vegetation regrowth characteristics can be distinctively delineated in drone imagery (Figure 3). There are grass species such as Calamagrostis epigejos or Carex arenaria that form large coherent patches. In contrast, Corynephorus canescens and 
Carex pilulifera occur as single spots in isolated growth patterns. Grass generally coexists with Calluna individuals in close range while high degrees of spatial interpenetration exists for Deschampsia flexuosa. Distinct patches of Calluna resprouting are separable from the background and from litter as well as from herb species such as Rumex acetosella that generates dense patches after mowing. Calluna resprouting mainly occurs in spatially adjacent shoot clusters, however, when the cluster density is high, small-scale variability $(<10.5 \mathrm{~cm})$ is spatially aggregated into coherent resprouting patches due to interpolation effects in the texture and after-classification filters.

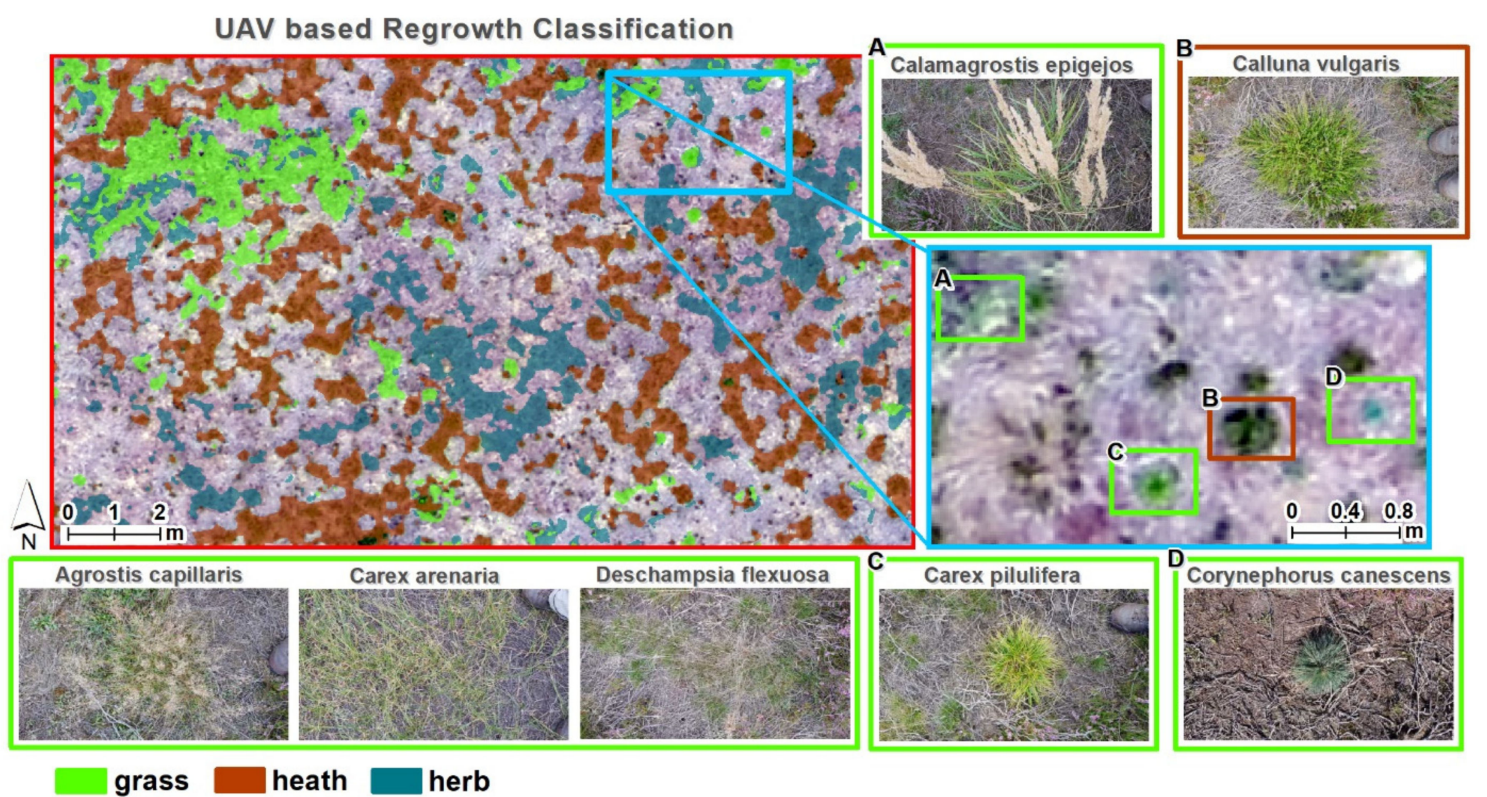

Figure 3. Classified patterns of after-mowing vegetation regrowth aggregated for different grass species; the image extent used is the red bounding box from Figure 1 using an unmanned aerial vehicle (UAV) image recorded at 27 July 2020.

Based on the classification of Calluna resprouting and grass species aggregation, the density values of both classes are mapped for the entire test site (Figure 4). Clear patterns of spatial heterogeneity are visible. There are areas where Calluna resprouting is completely suppressed while high density patches occur in distinct spatial locations. The density values are well defined over the complete range $(0 \ldots 100 \%)$ for both response variables. Grass encroachment can occur as closed patches or in association with Calluna resprouting. Besides, there are completely grass free areas.
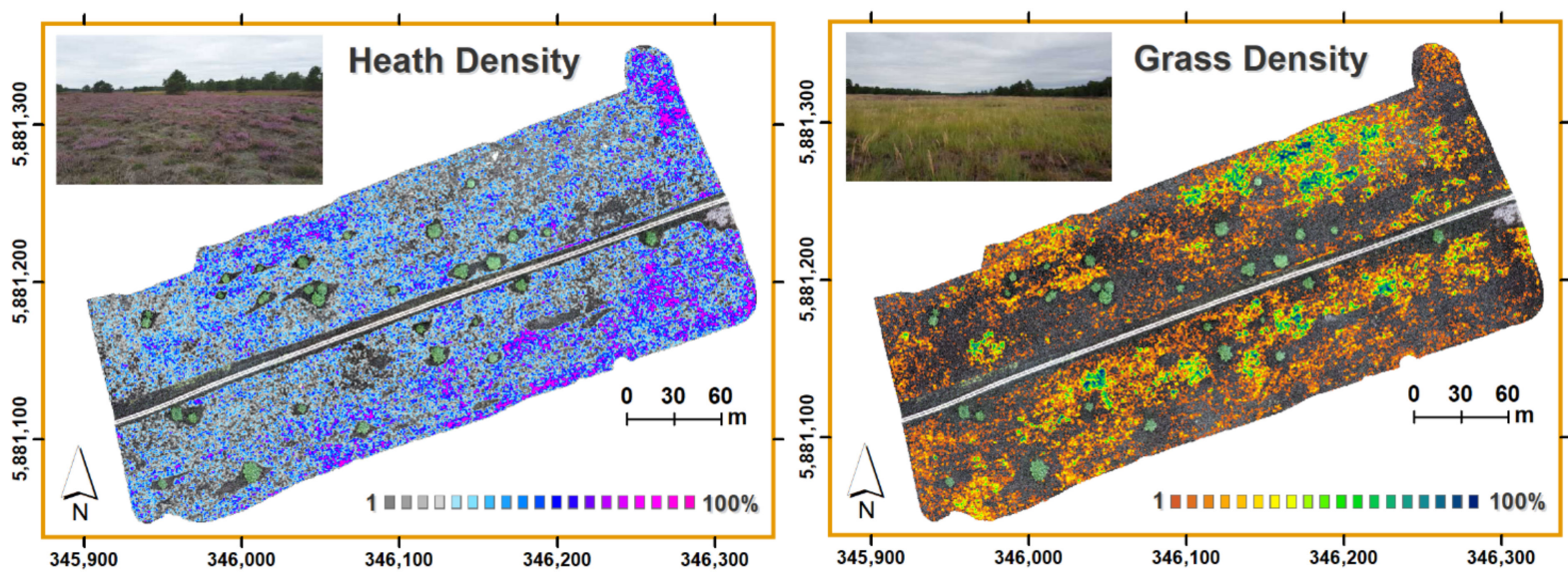

Figure 4. Density maps of two response variables, (left) resprouting Calluna heath and (right) aggregated grass species encroachment on the basis of $1 \mathrm{~m}^{2}$ sum filtered classification results. 


\subsection{The Predictive Potential of Calluna Resprouting and Grass Encroachment}

Regression analysis reveals highly significant spectral features for the prediction of Calluna resprouting indicating more than half of the predictor variables with $p$-value $<0.01$ in univariate regression. Variable selection results in a final multivariate linear regression model with uncorrelated features VIF $<3$ including the $5 \times 5$ mean filtered green channel, the green hsv-transformed channel and the index Daylight Adapted Vegetation Index (DAVI) belonging to the before mowing image of 06/04/2018 (Table 5). The three highest ranked predictors from random forest variable importance metric are mean filtered green, the green channels and the variance of a $5 \times 5$ focal filter on the green channel from the same drone acquisition. Thus, all selected predictors represent optical and structural traits of the green channel. Although random forest regression performance is high $\left(R^{2}=0.95\right)$ using all input predictors, the predictive accuracy in independent validation is decreased $\left(R^{2}=0.17\right)$. Multivariate regression of Calluna resprouting results in generally weaker accuracy $\left(R^{2}=0.15\right)$. Model performances are higher for the multivariate prediction of grass encroachment $\left(R^{2}=0.31\right)$ while predictor variables are mainly selected from structural features of texture dissimilarity and variance and from vegetation canopy heights (nDSM). Grass encroachment is further determined by DEM-based Topographic Wetness Index (TWI). Overfitting in random forest prediction is again high as indicated by high $\mathrm{R}^{2}$ difference between the final model $\left(R^{2}=0.94\right)$ and model validation $\left(R^{2}=0.38\right)$. Additionally, the red channel was highly ranked in predictive modeling. Unlike the models for Calluna resprouting, predictors for grass encroachment are equally selected from two acquisition dates.

Table 5. Model validation after predictor variable selection for the two response variables: a) Calluna resprouting and b) grass encroachment using two modeling techniques based on $n=1200$ samples and $n=100$ validation splits.

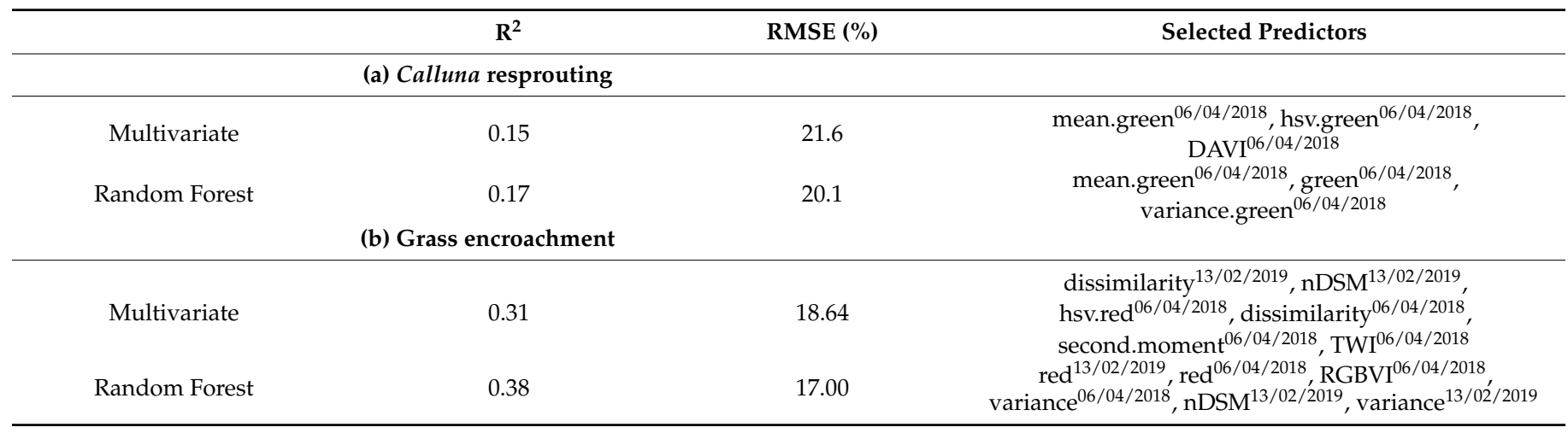

The final random forest models were applied on the before-mowing images to generate a spatially explicit evaluation of the potentials of Calluna resprouting and grass encroachment after mowing (Figure 5). There are clear structural patterns visible. Resprouting and grass encroachment is not necessarily negatively correlated on the spatial scale since patches with low resprouting densities can also be occupied by herbs (e.g., Rumex acetosella), shrubs (e.g., Rubus spec.) or small trees (e.g., Populus tremula juven.). Besides, grass can coexist with Calluna individuals due to interpenetration (mostly with Deschampsia flexuosa) or small-scale patch alternation. In consequence, an overlap of mean filtered resprouting potentials with high potentials of grass encroachment identifies patterns of coexistence and small-scale patch dynamics. 

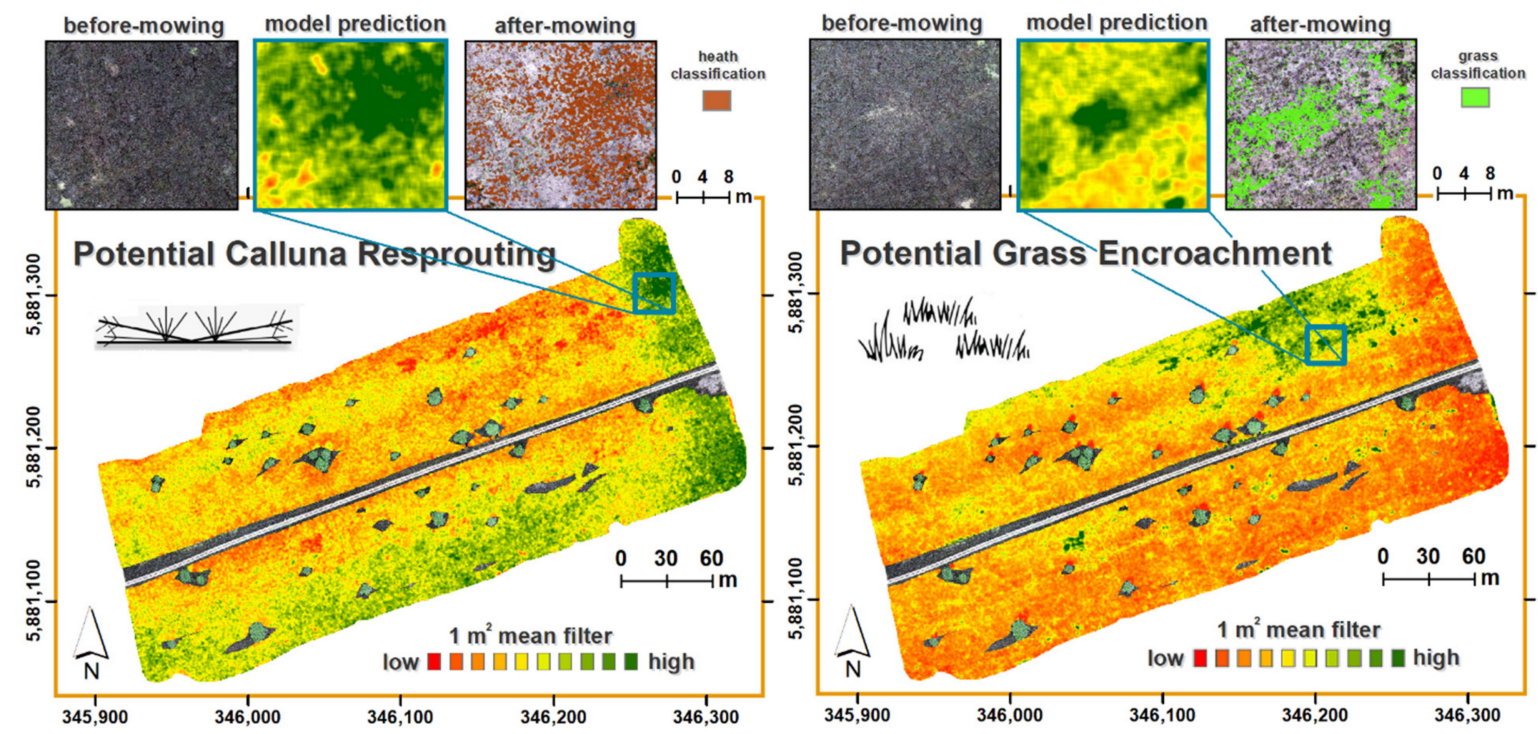

Figure 5. Drone based spatially explicit predictions of Calluna resprouting and grass encroachment after mowing using before-mowing plant optical traits and structural predictors.

\section{Discussion}

\subsection{The Predictive Values of Before-Mowing Stand Properties in UAV Imagery}

In our study, we identified plant optical and structural traits to indicate resprouting and grass encroachment prior to a destructive mowing event in a Calluna heathland. We derived diagnostic features of mature Calluna stands under the assumption that the intensity of resprouting is determined by genetic and physiological changes in a plant life-history context [5]. We found out that the density of Calluna vulgaris resprouting from buds at the stem base is significantly correlated to parental plant optical traits (mainly variations in green reflection). This is a strong indicator of distinct optical properties representing plant age at different growth phases in Calluna life-history. In particular, the growth phase of mature stands is characterized by a reduced photosynthetic activity due to long-shoot vigour reduction and lignification $[23,54]$. It is well known, that the production of young shoots of Calluna declines with age, starting in the mature life-cycle phase $[20,22,24,55]$. As a consequence, a change in plant vigour provides highly diagnostic signals to detect the regenerative potential of Calluna after plant biomass loss. However, the predictive performance of models from low-cost drones that are based on three visible RGB channels is still low. Recent advances in drone-based sensor technologies such as hyperspectral cameras [56] are potentially suitable to identify further optical predictors in narrow-band records of the full solar irradiance spectrum. In this regard, it can be expected to spectrally identify more biochemical and leaf structural variables over multitemporal intra- and inter-annual time series records [57].

Grass encroachment is known to be a major threat for heath ecosystems, particularly in continental dry heaths where the rate of generative rejuvenation is low [11]. Nitrogen deposition is recognized as the main controlling factor for such grass invasion [58], however, dispersal dynamics and the potential risk of habitat conversion under changing environmental conditions are poorly understood. Our study provides strong evidence that the expansion of the functional group of grasses into Calluna stands after mowing is not stimulated as seedling growth from the soil seedbank. In fact, our results show that grass has already established within the before-mowing Calluna population as either small-patchy growth or interpenetration. Thus, the spread of grass actually starts from existing spots that can be identified through structural traits such as canopy gaps for patchy growth or spectral dissimilarity for interpenetration.

Starting points for grass invasion are further coupled with significant correlations to the before-mowing red channel which can be an indicator for drought stress affecting 
chlorophyll-b content and thus reduces vital growth of parental Calluna individuals [57,59]. Such loss in vitality under rainfall deficits degrades resprouting rates which opens up niches for competing species. Climatic factors such as low rainfall during summer are known to significantly influence species composition following Calluna regeneration [60,61]. In this regard, the study reveals, that the competitive ability of grass species in comparison to Calluna for water usage can additionally be regulated by microrelief sinks. Such information is available in DEM based indices, however, further research is required to delineate single competitive factors. In particular, grass species discrimination in UAV imagery will provide a valid method to delineate varying species responses, e.g., Molinia arundinacea [62], Carex arenaria [63] or Deschampsia flexuosa [64], under changing environmental conditions in species rich heathlands. Additionally, our study indicates that structural predictors from different time periods between years increase the predictive power of models for grass invasion which has to be investigated in more detail using UAV records over full phenological cycles.

\subsection{Consequences for Nature Conservation Monitoring}

Although, accurate quantification of vegetation regeneration is considered to be the essential factor for prioritizing, planning and monitoring ecological restoration, the use of high-resolution UAV imagery in ecological recovery monitoring is still lagging behind [65]. Up to now, UAVs are solely used to record existing vegetation traits for mapping, e.g., post-fire dynamics such as damage (severity) and regeneration [66,67], post-mining rehabilitation of seedling establishment [68] or Calluna resprouting after controlled burning [19]. We show that even low-cost RGB drone cameras can be utilized to provide a more processesbased view on plant recovery and dispersal dynamics by linking Calluna stand properties and post-management patterns. It enables the implementation of a knowledge-driven decision support system for the selection of adequate habitat management measures. For example, since the development of Calluna life-cycle phases is not uniquely classifiable after plant age $[18,69]$, site specific environmental conditions and preceding management activities must be incorporated as population status indicator to evaluate the actual regenerative potential. This is particularly of utmost importance in continental dry heaths where seedling recruitment is low after mowing and burning $[11,17,19]$ and thus the potential resprouting capacity needs to be evaluated beforehand for maintaining a vital habitat status of Calluna heathland.

Small-scale UAV monitoring provides additional information on multitemporal patterns and arising dispersal dynamics that can be used to detect early change dynamics for supporting legally consolidated assessment schemes such as the European Natura 2000 network [70]. Conservationists are therein required to document development trends and to adopt suitable action against habitat conversion. In order to suppress grass encroachment in heathland ecosystems, it is for example required to effectively control the intensity and frequency of management measures, particularly under water stress and atmospheric nitrogen deposition that favors heathland conversion [61,64,71]. In this context, spatiotemporal patterns and dynamics will allow to define novel assessment criteria for a more process-based understanding of trends in managed ecosystems.

\section{Conclusions}

There are optical and structural traits that can be recorded using low-cost UAV RGB cameras to predict the potential of Calluna vulgaris resprouting and grass encroachment in managed heathlands. We found significant optical predictors for characterizing vital parental growth that can be linked to a higher resprouting density of Calluna after mowing. Furthermore, we identified structural anomalies by means of UAV based Calluna canopy modeling and texture filters in before-mowing scenes that can be related to grass patchy growth and interpenetration as starting points for grass species invasion after mowing. Although, predictive modeling still lacking additional spectral and temporal features from 
more advanced UAV sensor systems, first maps of the regenerative potential after mowing management of a heathland were derived in this study.

The results demonstrate that fine-scale UAV records can be utilized to design earlydetection schemes for habitat conversion and finally quantify vegetation change in space and time. In this regard, our study introduces the concept of trait propagation through time as a novel drone-based monitoring tool. It is based on preceding optical and structural stand characteristics that were related to future recovery potentials. For the first time, post-disturbance dynamics are mapped from UAV images that are recorded before the actual process of vegetation destruction. It enables an early quantification of Calluna resprouting and grass encroachment and thus provides a mean for the pre-evaluation of habitat conversion, that is of particular interest for an effective planning of active habitat management.

Author Contributions: Conceptualization, C.N.; methodology, C.N.; validation, C.N., A.S. and A.L., formal analysis, C.N.; investigation, C.N., A.S. and G.W.; resources, S.I.; data curation, C.N., A.S. and A.L.; writing—original draft preparation, C.N.; writing—review and editing, A.S., J.M., G.W. and S.I.; visualization, C.N.; supervision, S.I.; project administration, J.M. and S.I.; funding acquisition, C.N. and S.I. All authors have read and agreed to the published version of the manuscript.

Funding: The research is part of the F\&U-NBS-Verbund project NaTec - KRH. It is based on the "Federal Program on Biological Diversity", a funding program for the implementation of the "National Strategy on Biological Diversity" (NBS), launched by the Federal Ministry of Environment, Nature Conservation and Nuclear Safety. The project is funded by the Federal Ministry of Education and Research, Germany (BMBF) (grant number: 01 LC 1602A). The BMBF supports this project as research for sustainable development (FONA); www.fona.de. Project financing and supervision is accomplished by the German Aerospace Centre (DLR).

Institutional Review Board Statement: Not applicable.

Informed Consent Statement: Not applicable.

Data Availability Statement: The data presented in this study are available on request from the corresponding author.

Acknowledgments: The authors would like to express their special thanks to Heinz Sielmann Foundation and Bundesforst as part of Bundesanstalt für Immobilienaufgaben (BImA) for secure area access and information provided about management activities. We also thank Helmholtz Centre Potsdam GFZ for providing drones and infrastructure for save field trips and fast algorithm development.

Conflicts of Interest: The authors declare no conflict of interest.

\section{References}

1. Bond, W.J.; Midgley, J.J. Ecology of Sprouting in Woody Plants: The Persistence Niche. Trends Ecol. Evol. 2001, 16, 45-51. [CrossRef]

2. Vesk, P.A. Plant Size and Resprouting Ability: Trading Tolerance and Avoidance of Damage? J. Ecol. 2006, 94, 1027-1034. [CrossRef]

3. Pausas, J.G.; Pratt, R.B.; Keeley, J.E.; Jacobsen, A.L.; Ramirez, A.R.; Vilagrosa, A.; Paula, S.; Kaneakua-Pia, I.N.; Davis, S.D. Towards Understanding Resprouting at the Global Scale. New Phytol. 2016, 209, 945-954. [CrossRef] [PubMed]

4. Pausas, J.G.; Keeley, J.E. Evolutionary Ecology of Resprouting and Seeding in Fire-Prone Ecosystems. New Phytol. 2014, 204, 55-65. [CrossRef] [PubMed]

5. Clarke, P.J.; Lawes, M.; Midgley, J.J.; Lamont, B.; Ojeda, F.; Burrows, G.; Enright, N.; Knox, K. Resprouting as a Key Functional Trait: How Buds, Protection and Resources Drive Persistence after Fire. New Phytol. 2013, 197, 19-35. [CrossRef] [PubMed]

6. Zeppel, M.J.; Harrison, S.P.; Adams, H.D.; Kelley, D.I.; Li, G.; Tissue, D.T.; Dawson, T.E.; Fensham, R.; Medlyn, B.E.; Palmer, A.; et al. Drought and Resprouting Plants. New Phytol. 2015, 206, 583-589. [CrossRef] [PubMed]

7. Giljohann, K.M.; McCarthy, M.A.; Keith, D.A.; Kelly, L.T.; Tozer, M.G.; Regan, T.J. Interactions between Rainfall, Fire and Herbivory Drive Resprouter Vital Rates in a Semi-Arid Ecosystem. J. Ecol. 2017, 105, 1562-1570. [CrossRef]

8. Klimešová, J.; Klimeš, L. Resprouting of Herbs in Disturbed Habitats: Is It Adequately Described by Bellingham-Sparrow's Model? Oikos 2003, 103, 225-229. [CrossRef]

9. Midgley, J. Why the World's Vegetation Is Not Totally Dominated by Resprouting Plants; Because Resprouters Are Shorter than Reseeders. Ecography 1996, 19, 92-95. [CrossRef] 
10. Tälle, M.; Deák, B.; Poschlod, P.; Valkó, O.; Westerberg, L.; Milberg, P. Similar Effects of Different Mowing Frequencies on the Conservation Value of Semi-Natural Grasslands in Europe. Biodivers. Conserv. 2018, 27, 2451-2475. [CrossRef]

11. Henning, K.; von Oheimb, G.; Härdtle, W.; Fichtner, A.; Tischew, S. The Reproductive Potential and Importance of Key Management Aspects for Successful Calluna Vulgaris Rejuvenation on Abandoned Continental Heaths. Ecol. Evol. 2017, 7, 2091-2100. [CrossRef]

12. Bignal, E.M.; McCracken, D.I. The Nature Conservation Value of European Traditional Farming Systems. Environ. Rev. 2000, 8, 149-171. [CrossRef]

13. Webb, N. The Traditional Management of European Heathlands. J. Appl. Ecol. 1998, 35, 987-990. [CrossRef]

14. Fagúndez, J. Heathlands Confronting Global Change: Drivers of Biodiversity Loss from Past to Future Scenarios. Ann. Bot. 2012, 111, 151-172. [CrossRef]

15. Cordingley, J.E.; Newton, A.C.; Rose, R.J.; Clarke, R.T.; Bullock, J.M. Can Landscape-Scale Approaches to Conservation Management Resolve Biodiversity-Ecosystem Service Trade-Offs? J. Appl. Ecol. 2016, 53, 96-105. [CrossRef]

16. De Graaf, M.C.; Bobbink, R.; Smits, N.A.; Van Diggelen, R.; Roelofs, J.G. Biodiversity, Vegetation Gradients and Key Biogeochemical Processes in the Heathland Landscape. Biol. Conserv. 2009, 142, 2191-2201. [CrossRef]

17. Schellenberg, J.; Bergmeier, E. Heathland Plant Species Composition and Vegetation Structures Reflect Soil-Related Paths of Development and Site History. Appl. Veg. Sci. 2020, 23, 386-405. [CrossRef]

18. Schellenberg, J. Rethinking Relations between Age, Growth Phases and Vitality. In Proceedings of the 15th European Heathlands Network Workshop, Nijmegen, The Netherlands, 20-25 August 2017.

19. Neumann, C.; Behling, R.; Schindhelm, A.; Itzerott, S.; Weiss, G.; Wichmann, M.; Müller, J. The Colors of Heath FloweringQuantifying Spatial Patterns of Phenology in Calluna Life-Cycle Phases Using High-Resolution Drone Imagery. Remote Sens. Ecol. Conserv. 2020, 6, 35-51. [CrossRef]

20. Mohamed, B.; Gimingham, C. The Morphology of Vegetative Regeneration in Calluna Vulgaris. New Phytol. 1970, 69, 743-750. [CrossRef]

21. Matt Davies, G.; Adam Smith, A.; MacDonald, A.J.; Bakker, J.D.; Legg, C.J. Fire Intensity, Fire Severity and Ecosystem Response in Heathlands: Factors Affecting the Regeneration of Calluna Vulgaris. J. Appl. Ecol. 2010, 47, 356-365. [CrossRef]

22. Berdowski, J.; Siepel, H. Vegetative Regeneration of Calluna Vulgaris at Different Ages and Fertilizer Levels. Biol. Conserv. 1988, 46, 85-93. [CrossRef]

23. Gimingham, C.H. Ecology of Heathlands; Chapman and Hall: London, UK, 1972.

24. Miller, G.; Miles, J. Regeneration of Heather (Calluna Vulgaris (L.) Hull) at Different Ages and Seasons in North-East Scotland. J. Appl. Ecol. 1970, 7, 51-60. [CrossRef]

25. Sedláková, I.; Chytrỳ, M. Regeneration Patterns in a Central European Dry Heathland: Effects of Burning, Sod-Cutting and Cutting. Plant Ecol. 1999, 143, 77-87. [CrossRef]

26. Anderson, K.; Gaston, K.J. Lightweight Unmanned Aerial Vehicles Will Revolutionize Spatial Ecology. Front. Ecol. Environ. 2013, 11, 138-146. [CrossRef]

27. Müllerová, J.; Bartaloš, T.; Bruuna, J.; Dvořák, P.; Vítková, M. Unmanned Aircraft in Nature Conservation: An Example from Plant Invasions. Int. J. Remote Sens. 2017, 38, 2177-2198. [CrossRef]

28. Díaz-Delgado, R.; Cazacu, C.; Adamescu, M. Rapid Assessment of Ecological Integrity for LTER Wetland Sites by Using UAV Multispectral Mapping. Drones 2019, 3, 3. [CrossRef]

29. Baena, S.; Boyd, D.S.; Moat, J. UAVs in Pursuit of Plant Conservation-Real World Experiences. Ecol. Inform. 2018, 47, 2-9. [CrossRef]

30. Klosterman, S.; Melaas, E.; Wang, J.; Martinez, A.; Frederick, S.; O’Keefe, J.; Orwig, D.A.; Wang, Z.; Sun, Q.; Schaaf, C.; et al. Fine-Scale Perspectives on Landscape Phenology from Unmanned Aerial Vehicle (UAV) Photography. Agric. For. Meteorol. 2018, 248, 397-407. [CrossRef]

31. Jiménez López, J.; Mulero-Pázmány, M. Drones for Conservation in Protected Areas: Present and Future. Drones 2019, 3, 10. [CrossRef]

32. EU Council Directive 92/43/EEC of 21 May 1992 on the Conservation of Natural Habitats and of Wild Fauna and Flora. J. Eur. Union 1992, 11, 7-50.

33. Strecha, C.; Van Gool, L.; Fua, P. A Generative Model for True Orthorectification. In Proceedings of the ISPRS Congress, Beijing, China, 3-11 July 2008.

34. Küng, O.; Strecha, C.; Beyeler, A.; Zufferey, J.-C.; Floreano, D.; Fua, P.; Gervaix, F. The Accuracy of Automatic Photogrammetric Techniques on Ultra-Light UAV Imagery. In Proceedings of the UAV-g 2011-Unmanned Aerial Vehicle in Geomatics, Zurich, Switzeland, 14-16 September 2011.

35. Haralick, R.M.; Shanmugam, K.; Dinstein, I. Textural Features for Image Classification. IEEE Trans. Syst. Man Cybern. 1973, 3 , 610-621. [CrossRef]

36. Szantoi, Z.; Escobedo, F.; Abd-Elrahman, A.; Smith, S.; Pearlstine, L. Analyzing Fine-Scale Wetland Composition Using High Resolution Imagery and Texture Features. Int. J. Appl. Earth Obs. Geoinf. 2013, 23, 204-212. [CrossRef]

37. Gitelson, A.A.; Kaufman, Y.J.; Stark, R.; Rundquist, D. Novel Algorithms for Remote Estimation of Vegetation Fraction. Remote Sens. Environ. 2002, 80, 76-87. [CrossRef] 
38. Hunt, E.R., Jr.; Doraiswamy, P.C.; McMurtrey, J.E.; Daughtry, C.S.; Perry, E.M.; Akhmedov, B. A Visible Band Index for Remote Sensing Leaf Chlorophyll Content at the Canopy Scale. Int. J. Appl. Earth Obs. Geoinf. 2013, 21, 103-112. [CrossRef]

39. Bendig, J.; Yu, K.; Aasen, H.; Bolten, A.; Bennertz, S.; Broscheit, J.; Gnyp, M.L.; Bareth, G. Combining UAV-Based Plant Height from Crop Surface Models, Visible, and near Infrared Vegetation Indices for Biomass Monitoring in Barley. Int. J. Appl. Earth Obs. Geoinf. 2015, 39, 79-87. [CrossRef]

40. Louhaichi, M.; Borman, M.M.; Johnson, D.E. Spatially Located Platform and Aerial Photography for Documentation of Grazing Impacts on Wheat. Geocarto Int. 2001, 16, 65-70. [CrossRef]

41. Woebbecke, D.M.; Meyer, G.E.; Von Bargen, K.; Mortensen, D.A. Color Indices for Weed Identification under Various Soil, Residue, and Lighting Conditions. Trans. ASAE 1995, 38, 259-269. [CrossRef]

42. Hague, T.; Tillett, N.; Wheeler, H. Automated Crop and Weed Monitoring in Widely Spaced Cereals. Precis. Agric. 2006, 7, 21-32. [CrossRef]

43. Marchant, J.A.; Onyango, C.M. Shadow-Invariant Classification for Scenes Illuminated by Daylight. JOSA A 2000, $17,1952-1961$. [CrossRef] [PubMed]

44. Böhner, J.; Selige, T. Spatial Prediction of Soil Attributes Using Terrain Analysis and Climate Regionalisation. Göttinger Geogr. Abh. 2006, 115, 13-28.

45. Moore, I.D.; Grayson, R.; Ladson, A. Digital Terrain Modelling: A Review of Hydrological, Geomorphological, and Biological Applications. Hydrol. Process. 1991, 5, 3-30. [CrossRef]

46. Breiman, L. Random Forests. Mach. Learn. 2001, 45, 5-32. [CrossRef]

47. Liaw, A.; Wiener, M. Classification and Regression by RandomForest. R News 2002, 2, 18-22.

48. Story, M.; Congalton, R.G. Accuracy Assessment: A User's Perspective. Photogramm. Eng. Remote Sens. 1986, 52, $397-399$.

49. Cutler, D.R.; Edwards, T.C.; Beard, K.H.; Cutler, A.; Hess, K.T.; Gibson, J.; Lawler, J.J. Random Forests for Classification in Ecology. Ecology 2007, 88, 2783-2792. [CrossRef]

50. Akaike, H. Information Theory and an Extension of the Maximum Likelihood Principle. In Selected Papers of Hirotugu Akaike; Springer: Berlin, Germany, 1973.

51. Fox, J.; Monette, G. Generalized Collinearity Diagnostics. J. Am. Stat. Assoc. 1992, 87, 178-183. [CrossRef]

52. Belkin, M.; Hsu, D.J.; Mitra, P. Overfitting or Perfect Fitting? Risk Bounds for Classification and Regression Rules That Interpolate. In Proceedings of the Advances in Neural Information Processing Systems, Montreal, QC, USA, 2-8 December 2018; pp. $2300-2311$.

53. Wyner, A.J.; Olson, M.; Bleich, J.; Mease, D. Explaining the Success of Adaboost and Random Forests as Interpolating Classifiers. J. Mach. Learn. Res. 2017, 18, 1558-1590.

54. Watt, A.S. Bracken Versus Heather, A Study in Plant Sociology. J. Ecol. 1955, 43, 490. [CrossRef]

55. Barclay-Estrup, P. The Description and Interpretation of Cyclical Processes in a Heath Community: II. Changes in Biomass and Shoot Production during the Calluna Cycle. J. Ecol. 1970, 58, 243-249. [CrossRef]

56. Arroyo-Mora, J.P.; Kalacska, M.; Inamdar, D.; Soffer, R.; Lucanus, O.; Gorman, J.; Naprstek, T.; Schaaf, E.S.; Ifimov, G.; Elmer, K.; et al. Implementation of a UAV-Hyperspectral Pushbroom Imager for Ecological Monitoring. Drones 2019, 3, 12. [CrossRef]

57. Mac Arthur, A.; Malthus, T. Calluna Vulgaris Foliar Pigments and Spectral Reflectance Modelling. Int. J. Remote Sens. 2012, 33, 5214-5239. [CrossRef]

58. Heil, G.; Bobbink, R. Impact of atmospheric nitrogen deposition on dry heathlands. In Heathlands; Springer: Berlin, Germany, 1993; pp. 181-200.

59. Neumann, C.; Itzerott, S.; Weiss, G.; Kleinschmit, B.; Schmidtlein, S. Mapping Multiple Plant Species Abundance Patterns-A Multiobjective Optimization Procedure for Combining Reflectance Spectroscopy and Species Ordination. Ecol. Inform. 2016, 36, 61-76. [CrossRef]

60. Britton, A.; Carey, P.; Pakeman, R.; Marrs, R. A Comparison of Regeneration Dynamics Following Gap Creation at Two Geographically Contrasting Heathland Sites. J. Appl. Ecol. 2000, 37, 832-844. [CrossRef]

61. Britton, A.J.; Pakeman, R.J.; Carey, P.D.; Marrs, R.H. Impacts of Climate, Management and Nitrogen Deposition on the Dynamics of Lowland Heathland. J. Veg. Sci. 2001, 12, 797-806. [CrossRef]

62. Probo, M.; Ascoli, D.; Lonati, M.; Marzano, R.; Lombardi, G. Restoration Treatments to Control Molinia Arundinacea and Woody and Alien Species Encroachment in Calluna Vulgaris Heathlands at the Southern Edge of Their Distribution. Biol. Conserv. 2017, 211, 102-109. [CrossRef]

63. Remke, E.; Brouwer, E.; Kooijman, A.; Blindow, I.; Esselink, H.; Roelofs, J.G. Even Low to Medium Nitrogen Deposition Impacts Vegetation of Dry, Coastal Dunes around the Baltic Sea. Environ. Pollut. 2009, 157, 792-800. [CrossRef] [PubMed]

64. Britton, A.; Marrs, R.; Carey, P.; Pakeman, R. Comparison of Techniques to Increase Calluna Vulgaris Cover on Heathland Invaded by Grasses in Breckland, South East England. Biol. Conserv. 2000, 95, 227-232. [CrossRef]

65. Buters, T.M.; Bateman, P.W.; Robinson, T.; Belton, D.; Dixon, K.W.; Cross, A.T. Methodological Ambiguity and Inconsistency Constrain Unmanned Aerial Vehicles as a Silver Bullet for Monitoring Ecological Restoration. Remote Sens. 2019, 11, 1180. [CrossRef]

66. Carvajal-Ramírez, F.; Marques da Silva, J.R.; Agüera-Vega, F.; Martínez-Carricondo, P.; Serrano, J.; Moral, F.J. Evaluation of Fire Severity Indices Based on Pre-and Post-Fire Multispectral Imagery Sensed from UAV. Remote Sens. 2019, 11, 993. [CrossRef]

67. Larrinaga, A.R.; Brotons, L. Greenness Indices from a Low-Cost UAV Imagery as Tools for Monitoring Post-Fire Forest Recovery. Drones 2019, 3, 6. [CrossRef] 
68. Buters, T.M.; Belton, D.; Cross, A.T. Multi-Sensor UAV Tracking of Individual Seedlings and Seedling Communities at Millimetre Accuracy. Drones 2019, 3, 81. [CrossRef]

69. Gimingham, C. A Reappraisal of Cyclical Processes in Calluna Heath. Vegetatio 1988, 77, 61-64. [CrossRef]

70. Schmidt, J.; Fassnacht, F.E.; Neff, C.; Lausch, A.; Kleinschmit, B.; Förster, M.; Schmidtlein, S. Adapting a Natura 2000 Field Guideline for a Remote Sensing-Based Assessment of Heathland Conservation Status. Int. J. Appl. Earth Obs. Geoinf. 2017, 60, 61-71. [CrossRef]

71. Barker, C.G.; Power, S.A.; Bell, J.; Orme, C. Effects of Habitat Management on Heathland Response to Atmospheric Nitrogen Deposition. Biol. Conserv. 2004, 120, 41-52. [CrossRef] 